ISSN : 2087-2461

PENANGGUNG JAWAB Dekan FIKOM

Trimanah, M.Si.

Sekretaris Dekan

Dian Marhaeni K, M.Si

Ketua Penyunting Made Dwi Adnjani, M.Si

Sekretaris

Mubarok, M.Si

Bendahara

Umi Hidayah, S.H.

Dewan Penyunting

Trimanah, M.Si

Edi Ismoyo, M.Si

Suharyoso, S.Sos

Seksi Usaha

Endang Winarsih, S.Sos

Sirkulasi dan Distribusi

Novi, S.Sos

Alamat Redaksi

Fakultas Ilmu Komunikasi

Universitas Islam

Sultan Agung Semarang

Jl. Raya Kaligawe Km. 4

Po. Box 1054/SM

Semarang 50112

Telp. (024) 6583584

ext. $448 / 449$

Fax. (024) 6582455

email : jurnalfikom@yahoo.com
Inovasi Digital Public Relations Pada

Perguruan Tinggi Swasta di Kota Semarang

dalam Meningkatkan Citra

Agus Triyono

agustriyono7@gmail.com

119-126

Eksistensi Buruh Dalam Komunikasi Bipartit

(Upaya Membangun Kemitraan Antara

Buruh dan Pengusaha Secara Ideal di Kota Kretek)

Muhammad Zakki Mubarok

$127-139$

Implementasi Konsep Diri Pada Kelompok Gemes

(Gemuk Menawan Semarang)

Kajian Teoritis Psikologi Komunikasi tentang

Konsep Diri Pada Kelompok Gemes

(Gemuk Menawan Semarang)

Genta Maghvira

140-149

Representasi Perempuan dalam

Film Cinta Suci Zahrana

Urip Mulyadi

$150-158$

Kapitalisme, Budaya Dunia, Internasionalisasi Bahasa dan Nilai-Nilai Islam Pada Tayangan Periklanan Anak di Media Televisi Dalam Perspektif Bidang Kreatif Industri Periklanan

Dian Marhaeni Kurdaningsih

marhaeni@unissula.ac.id

159-172

Paparan Media Promosi Kesehatan

Dengan Pengetahuan Pencegahan Infeksi

Bagi Pengunjung Rumah Sakit

Besar Tirto Husodo

e-mail : besarundip4@gmail.com

Puspa Run Canti

173-177

Model Kampanye Pilkada Atasi Politik Uang

dan Sikap Pesimis Pemilih

(Telaah teoritis dan konsep implementasinya)

Hariyani

nhyani812@gmail.com

178-193 


\title{
EKSISTENSI BURUH DALAM KOMUNIKASI BIPARTIT (Upaya Membangun Kemitraan Antara Buruh dan Pengusaha Secara Ideal di Kota Kretek)
}

\author{
Muhammad Zakki Mubarok \\ Mahasiswa MIKOM UNDIP Angk. V
}

\begin{abstract}
The industrial relations led to disputes, particularly between employers and workers. This is due to differences in perception between the two sides. Before the dispute widened, the internal communication in the company is required. In the labor, such communication commonly called a bipartite negotiations. Negotiations involving the employer, even the management or his representative, with the workers, even it unions or representatives.

Kudus as an industrial city, has not seen any volatility in labor disputes that lead to anarchy. However, that does not mean escape from the clash at all. The question is whether bipartite communications with all its mechanisms have actually executed in the labor segment in Kudus. So the extent to which the workers understand the rules in bipartite negotiations.

The method in this study using a phenomenological approach, aiming to obtain a full picture of the problems that occur between employers and workers. The results in this study indicate that communication between employers and employees is almost no constraints except the factor of labor education levels are low. It then may present barriers to understanding the conditional relations, cultural and functional, although the true communication goes smoothly.
\end{abstract}

Keywords: communication, bipartite negotiations, industrial relations, industrial disputes

\begin{abstract}
Abstrak
Hubungan industrial rentan memunculkan perselisihan, terutama antara pihak pengusaha dan buruh. Hal tersebut dikarenakan adanya perbedaan persepsi di antara kedua belah pihak. Sebelum perselisihan tersebut melabar, maka dibutuhkan komunikasi di tingkat internal perusahaan. Dalam perburuhan komunikasi tersebut biasa disebut dengan perundingan bipartit. Perundingan yang melibatkan pihak pengusaha, bisa manajemen atau yang mewakilinya, dengan pihak buruh, bisa serikat pekerja atau yang mewakilinya.

Kudus sebagai kota industri, selama ini tidak terlihat adanya gejolak perselisihan dalam perburuhan yang mengarah kepada tindakan anarkis. Namun demikian bukan berarti lepas dari persilisihan sama sekali. Yang menjadi pertanyaan adalah apakah komunikasi bipartit dengan segala mekanismenya telah betul-betul dijalankan dalam dunia perburuhan di Kudus. Lantas sejauh manakah para buruh memahami peraturan dalam perundingan bipartit.

Metode dalam penelitian ini menggunakan pendekatan fenomenologi, bertujuan untuk memperoleh gambaran secara utuh mengenai permasalahan-permasalahan yang terjadi di antara pengusaha dan buruh. Hasil dalam penelitian ini menunjukkan bahwa komunikasi di antara pengusaha dan buruh hampir tidak ada kendala kecuali faktor tingkat pendidikan buruh yang rendah. Hal tersebut kemudian dapat menimbulkan hambatan dalam memahami hubungan kondisional, cultural dan fungsional, meskipun sejatinya komunikasi berjalan lancar.
\end{abstract}

Kata Kunci : komunikasi, perundingan bipartit, hubungan industrial, perselisihan hubungan industrial 


\section{Pendahuluan}

Dalam sebuah hubungan industrial rentan memunculkan permasalahan dan bahkan perselisihan antara pihak manajemen dan buruh. Permasalahan ini sering terjadi karena perbedaan persepsi antar kedua belah pihak. Sebelum permasalahan itu meluas, maka dibutuhkan komunikasi di tingkat internal untuk merundingkan permasalahan itu yang melibatkan kedua belah pihak. Dalam dunia peburuhan, istilah perundingan ini disebut bipartit.

Komunikasi bipartit secara umum telah diterapkan di berbagai industri (perusahaan) yang ada di Kudus. Komunikasi yang baik akan menghasilkan sebuah kemitraan yang kokoh di antara kedua belah pihak (pengusaha dan buruh). Demikian pula sebaliknya apabila komunikasi yang terjadi tidak baik maka akan terjadi demo buruh (Hafsah, 1999) diantaranya demo yang dilakukan oleh buruh PT Armada Mekar Jaya (MAJ) yang berada di Jalan Diponegoro No 107, Tambun Selatan, Kabupaten Bekasi. Sebanyak 150 pekerja, menuntut pihak perusahaan lantaran melakukan pemutusan hak kerja (PHK) sepihak. (Antara News, 5 Nopember 2015).

Hal serupa dilakukan oleh sekitar 500 buruh yang tergabung dalam Serikat Buruh Garmen Tekstil dan Sepatu-Gabungan Serikat Buruh Independen (SBGTS-GSBI) PT Megariamas Sentosa. Mereka menuntut pemerintah mengambil tindakan tegas terhadap perusahaan yang mempekerjakan mereka karena mangkir memberikan tunjangan hari raya (THR). (Antara News, 9 September 2015).

Negarainisebenarnyatelahmerumuskan dan menetapkan sistem ekonomi termasuk hubungan antara pengusaha dan buruh. Hal ini tercantum dalam Pasal 33 ayat (1) UndangUndang Dasar 1945: "Perekonomian nasional diselenggarakan berdasar atas demokrasi ekonomi dengan prinsip kebersamaan, efisiensi berkeadilan, berkelanjutan, berwawasan lingkungan, kemandirian, serta dengan menjaga keseimbangan kemajuan dan kesatuan ekonomi nasional".

Pada penjelasan Pasal 33 Ayat (1) menyebutkan produksi dilakukan oleh semua untuk semua untuk membangun kemakmuran bersama, bukan orang perorang. Tersirat makna bahwa pada hakikatnya perusahaan adalah usaha bersama antara pengusaha sebagai pemilik modal dan teknologi dengan pekerja atau buruh yang menjalankan dan mengembangkan modal dan teknologi dengan tenaga, pikiran dan kemampuan yang dimiliki pengusaha dan pekerja sama-sama bekerja sesuai fungsi dan peran masing-masing dengan satu tekad dan tujuan, yaitu keuntungan perusahaan dan kesejahteraan bersama.

Hakikat itu sejalan dan senafas dengan jiwa dan semangat gotong royong sebagaimana diatur dalam Undang-Undang Dasar 1945 yang menjadi modal sosial terbesar untuk membangun perekonomian bangsa Indonesia. Buruh bukanlah 'pelayan pengusaha' melainkan 'mitra yang setara dengan pengusaha' dalam membangun perekonomian Indonesia (Jehani, 2007), tidak terkecuali di Kota Kudus.

Meskipun berjuluk Kota Kretrek, di Kudus tidak hanya memiliki perusahaan rokok saja, namun Kudus juga memiliki perusahaan besar selain perusahaan rokok. Beberapa perusahaan besar yang berskala nasional dan memiliki banyak tenaga kerja, diantaranya:

\begin{tabular}{|c|l|l|}
\hline No. & \multicolumn{1}{|c|}{ Nama Perusahaan } & \multicolumn{1}{c|}{ Alamat } \\
\hline 1 & PT. NOJORONO TOBACO INTERNASIONAL & Jln. Jend. Sudirman No. 86 B - Kudus \\
\hline 2 & PT. DJARUM & Jln. Jend Ahmad Yani No 28 - Kudus \\
\hline 3 & PT. Pura Barutama & Jl. AKBP Agil Kusumadya No. 203, Kudus \\
\hline 4 & PT. Pura Nusapersada & Jl. AKBP Agil Kusumadya Km. 4, Kudus \\
\hline 5 & PR Sukun & $\begin{array}{l}\text { Jl. Raya PR Sukun No. 1-2 RT02 RW06, } \\
\text { Gondosari, Gebog, Jawa Tengah 59354, Indonesia }\end{array}$ \\
\hline 6 & PT.MUBAROKFOOD CIPTA DELICIA & Jl. Sunan Muria 33 Kudus \\
\hline 7 & Polytron Kudus & Jalan KH.R.Asnawi P.O. Box 126 Kudus \\
\hline
\end{tabular}


Adapun perusahaan Industri menurut jumlah tenaga kerja sebagai mana tabel kecamatan jumlah tenaga kerja berdasarkan berikut: hasil sensus yang dilakukan oleh BPS Kudus

Jumlah Perusahaan Industri Besar/Sedang

Menurut Kecamatan di Kabupaten Kudus Tahun 2013

\begin{tabular}{ccccc} 
Kecamatan & District & Besar/Big & \multicolumn{2}{c}{ Sedang/Medium } \\
\hline & Usaha & Tenaga Kerja & Usaha & Tenaga Kerja \\
Business & Labour & Business & Labour \\
\hline$(1)$ & $(2)$ & $(3)$ & $(4)$ & $(5)$ \\
\hline
\end{tabular}

1. Kaliwungu

2. Kota

3. Jati

4. Undaan

5. Mejobo

6. Jekulo

7. Bae

8. Gebog

9. Dawe

$\begin{array}{rrr}25.035 & 14 & 661 \\ 17.704 & 28 & 1.001 \\ 18.072 & 11 & 393 \\ 0 & 7 & 221 \\ 4.254 & 8 & 262 \\ 8.637 & 4 & 151 \\ 10.044 & 8 & 375 \\ 11.407 & 15 & 518 \\ 0 & 3 & 155\end{array}$

$\begin{array}{llllll}2013 & 83 & 95.153 & 98 & 3.737 \\ 2012 & 86 & 94.744 & 91 & 3.888 \\ \text { Jumlah } & 79 & 92.529 & 87 & 3.584 \\ & 2011 & 80 & 92.506 & 89 & 3.962 \\ & 2010 & 81 & 92.551 & 98 & 4.005\end{array}$

Sumber : Badan Pusat Statistik ( BPS ) Kabupaten Kudus

Source : BPS-Statistics of Kudus

Tentu tidak mudah mengelola hubungan buruh dengan perusahaan agar selalu harmonis. Pengusaha harus memberikan kebebasan kepada buruh untuk berserikat, berkumpul dan mengeluarkan pendapat melalui saluran yang seharusnya (Nurachmad, 2009). Pekerja di Kota Kudus juga telah menjadi anggota pada serikat pekerja yang ada di Indonesia, serikat pekerja tersebut di antaranya :

1. Konfederasi Serikat Pekerja Seluruh Indonesia $=$ KSPSI (hasil Munas) Ketua Umum: Syukur Sarto Jl. Raya Pasar Minggu Km. 17, no. 9, Jakarta Selatan 12740 021-7974359 / 021-7988212 / 021 7974361. Email: syukurst@centrin.net.id

2. Federasi Serikat Pekerja Seluruh Indonesia Reformasi $=$ FSPSI Reformasi Ketua $: \mathrm{H}$. Muhammad Rodja J1. Elang Mas I, C5/17, Perumahan Tanjung Emas, Tanjung Barat
3. Federasi Serikat Buruh Demokrasi Seluruh Indonesia $=$ FSBDSI Ketua : Abdoel Azis Riambo Jl. Raya Kebon Jeruk no. 4, RT 002 RW 13, Kel. Palmerah, Rawabelong, Jakarta Barat 11480 021-5438615 / 0215438615

4. Serikat Buruh Sejahtera Indonesia $=$ SBSI Ketua: Muchtar Pakpahan Ds. Jeungging Kecamatan Cisoka, Kabupaten Tangerang, Banten 021-5993047 021-5993048 021599 3053. Email: sbsi@pacific.net.id

5. Sarekat Buruh Muslimin Indonesia $=$ SARBUMUSI Ketua: H. Sutanto Martoprasono Jl. H. Soleh II no. 22A, Kel. Sukabumi Selatan, Kebon Jeruk, Jakarta Barat 11560 021-53670238 / 021 53671692 
6. Persaudaraan Pekerja Muslimin Indonesia = PPMI Ketua: Eggi Sudjana Jl. Tebet Dalam IV i no. 33, Tebet, Jakarta 12810 021-8353315 / 021-8353316. Email: info@ppmi.or.id

7. Gabungan Serikat Pekerja Merdeka Indonesia GASPERMINDO Ketua: Moh. Jumhur Hidayat Jl. Budi no. 3A, Cawang III, Dewi Sartika, Jakarta Timur 0218091128 / 021-8091128

8. Gabungan Serikat Buruh Industri Indoensia = GASBIINDO Ketua: H. Agus Sudono J1. Tebet Barat Dalam Raya no. 15, Jakarta Selatan 12810 021-8353631 021-8353632 / 021-8290289. Email: gasbiindo@wowmail.com

9. Asosiasi Serikat Pekerja Indonesia = ASPEK Indonesia Ketua: Jenal Kaludin Jl.Tebet Dalam III/29, Jakarta Selatan 12810 021-8303040 / 021-8308309 / 8305132 021-8308310. Email: aspek@ link.net.id

Dengan kemitraan yang terjalin baik antara buruh dan pengusaha, gejolak ataupun konflik antara pengusaha dan buruh tidak akan terjadi (Tjandra, 2003). Banyak di daerah lain yang menerapkan hal yang sama, tetapi hasilnya sering menyisakan gejolak perburuhan yang berakhir dengan demonstrasi yang bersifat anarkis. Perburuhan di Kudus, kendati jumlah tenaga kerja (buruh) yang terserap di sektor industri sangat besar (lebih dari 250.000 pekerja/buruh) (BPS Kudus), namun masalah perburuhan di kota kretek ini nyaris tidak pernah terdengar, kecuali hanya riak-riak kecil yang tidak berpengaruh pada kondusivitas daerah.

Bila dibandingkan dengan perselisihan hubungan industrial di kota-kota lain yang terkesan sering mengalami kebuntuan tentunya merupakan sesuatu yang menarik untuk dikaji. Meskipun begitu, tidak menutup kemungkinan akan terjadi gesekan-gesekan pada tingkat perusahaan di kemudian hari, misalnya terkait UMR ataupun UMK yang tergolong rendah dan tidak sesuai KHL menurut buruh dan perwakilannya, namun sebaliknya menurut para pengusaha. Dari sinilah kemudian komunikasi yang terjalin di tingkat perusahaan akan dikaji.

\section{Metode Penelitian}

Penelitianinibersifatdeskriptifdengan menggunakan pendekatan fenomenologi, lebih tepatnya yaitu fenomenologi persepsi, dengan mempercayai bahwa suatu kebenaran bisa didapatkan dari sudut pandang yang berbeda-beda, tidak hanya membatasi fenomenologi pada obyektifitas namun subyektifitas juga mengambil perannya (Kuswara, 2005). Buruh beserta pihaknya mempunyai pengalaman tentang peranan komunikasi antara mereka dengan pihak pengusaha atau perusahaan dalam kurun waktu tertentu. Hal ini bertujuan untuk memperoleh gambaran secara utuh mengenai permasalahan-permasalahan yang terjadi di antara kedua belah pihak.

Dalam penelitian ini akan dipelajari materi-materi mengenai komunikasi organisasi maupun norma-norma yang berlaku dalam sebuah hubungan perindustrian, juga mekanisme penyelesaian dalam perselisihan hubungan industrial. Penelitian ini juga akan mempelajari bagaimana komunikasi mengambil peran penting dalam aspek-aspek empiris dari proses ataupun mekanisme penyelesaian PHI di lapangan.

Selanjutnya proses dalam penelitian fenomenologi terdiri dari 3 tahap, yaitu pralapangan, lapangan, dan deskripsi. (Mudjiyanto dan Kenda, 2011: 67-68). Tahap pralapangan, dimana peran peneliti lebih dominan, artinya peneliti secara total masuk dalam permasalahan disamping tetap berempati dan menghargai ungkapan informan pada fenomena yang diteliti. Ini merupakan proses dimana peneliti mulai tahu tetang fenomena yang digambarkan informan. Peneliti bersifat alami tanpa mempengaruhi informan.

Berikutnya dalam tahap lapangan, peneliti harus mengidentifikasi intisari fenomena tentang bagaimana persepsi buruh tentang kebijakan-kebijakan perusahan atas kebutuhan mereka berdasarkan data-data yang diperoleh dari informan. Pada tahap ini peneliti melakukan identifikasi dengan sangat teliti dan cermat untuk memperoleh keakuratan dan 
kemurnian hasil sesuai dengan pengalaman informan.

Tahap deskripsi merupakan tahap terakhir dari fenomenologi deskriptif. Pada tahap ini peneliti membuat narasi yang luas dan mendalam mengenai fenomena yang diteliti. Deskripsi bertujuan untuk mengkomunikasikan arti komunikasi bipartit dalam membangun kemitraan sesuai pandangan informan. Ketiga langkah tersebut merupakan satu kesatuan dalam pemahaman arti dan makna menggunakan pendekatan fenomenologi deskriptif dan pelaksanaannya dilakukan secara berurutan.

\section{Pembahasan}

Bipartit sebagaimana dikatakan Bimoprasetio adalah sebuah forum penyelesaian internal antara pengusaha dan pekerja. Forum ini akan mengacu pada forum komunikasi, konsultasi dan membuat pertimbangan yang matang tentang persoalan yang berkaitan dengan hubungan industrial, yang anggotanya terdiri dari para pengusaha dan para pekerja atau organisasi pekerja (buruh) ataupun perwakilan yang dibentuk buruh. (Bimoprasetio. http://strategihukum. net/kiat-sukses-pengusaha-berunding-bipartitalam-perselisihan-hubungan-industrial.

Maret 2014).

Bipartit adalah sebuah lembaga yang wajib dimiliki oleh setiap perusahaan yang mempekerjakan (minimal) 50 orang buruh atau lebih. Lembaga ini juga merupakan forum komunikasi dan konsultasi serta sebagai lembaga penyelesaian perselisihan perburuhan mengenai hal ketenagakerjaan di perusahaan antara perusahaan atau perwakilan buruh dan majikan.

Lingkup penyelesaian hubungan industrial melalui bipartit mencakup keempat jenis perselisihan, yakni perselisihan hak, perselisihan kepentingan, perselisihan PHK, dan perselisihan antara pekerja atau serikat buruh dalam suatu perusahaan. (Tjandra, 2003: 28).

Inti dari hubungan bipartit adalah musyawarah untuk mencapai mufakat, atau dalam istilah lain disebut penyelesaian masalah secara kekeluargaan. Bipartit merupakan mandatory rules yang wajib ditempuh oleh para pihak yang berselisih sebelum melangkah ke proses berikutnya. Hal ini berdasarkan sistem penyelesaian perselisihan hubungan industrial di Indonesia.

Kewajiban itu diatur dalam Pasal 3 ayat 1 UU No. 2 Tahun 2004 Tentang Penyelesaian Perselisihan Hubungan Industrial: "Perselisihan hubungan industrial wajib diupayakan penyelesaiannya terlebih dahulu melalui perundingan bipartit secara musyawarah untuk mencapai mufakat".

Lembaga bipartit sebagai wadah komunikasi dalam hubungan industrial pun bukan tanpa masalah. Undang-undang atau peraturan pelaksanaan di forum ini sering kali dipandang hanya menguntungkan pihak manajemen perusahaan (majikan). Peraturanperaturan di dalamnya tidak memberikan keterangan yang banyak tentang apa yang harus dicakup oleh komunikasi dan konsultasi tersebut (Winarko, 2010).

Peraturan pelaksanaan hanya menentukan bahwa lembaga kerjasama bipartit berfungsi "sebagai forum komunikasi, konsultasi, dan musyawarah antara pengusaha dan wakil serikat pekerja/serikat buruh atau pekerja/buruh pada tingkat perusahaan..." (KEPMENAKERTRANS 255/MEN/2003 Pasal 2). Ini berarti tidak ada keterangan yang jelas mengenai isu apa yang boleh dibahas dan yang tidak boleh dibahas.

Jadi dalam hal ini dipandang sangat penting bagi serikat pekerja untuk menentukan ketentuan-ketentuan dasar di dalam pertemuan-pertemuan forum bipartit tentang masalah apa yang boleh dibahas secara terbuka dan masalah apa yang hanya akan dibahas di dalam perjanjian kerja bersama.

Beberapa penelitian dan hasilnya di bawah ini menunjukkan bahwa perundingan bipartit ada kalanya berjalan mulus dan bisa juga terhambat, 
Eksistensi Buruh Dalam Komunikasi Bipartit (Upaya Membangun Kemitraan Antara Buruh dan Pengusaha Secara Ideal di Kota Kretek)

\begin{tabular}{|c|c|c|c|c|c|}
\hline No. & Penelitian & Oleh & Temuan & Masalah & Hasil \\
\hline 1 & $\begin{array}{l}\text { Penelitian } \\
\text { Hukum Tentang } \\
\text { Penyelesaian } \\
\text { Perselisihan } \\
\text { Hubungan } \\
\text { Industrial }\end{array}$ & $\begin{array}{l}\text { Tim BPHN } \\
\text { dibawah pimpinan } \\
\text { Suherman Toha, } \\
\text { SH., MH., APU }\end{array}$ & $\begin{array}{l}\text { adanya upaya } \\
\text { pemerintah untuk } \\
\text { mencegah dan } \\
\text { mengatasi terjadinya } \\
\text { perselisihan } \\
\text { hubungan industrial, } \\
\text { namun belum } \\
\text { optimal sesuai } \\
\text { tuntutan masyarakat } \\
\text { industrial }\end{array}$ & $\begin{array}{l}\text { UU No. } 2 \text { tahun } \\
2004 \text { tentang } \\
\text { penyelesaian PHI } \\
\text { terlalu formal, } \\
\text { khususnya bagi } \\
\text { pihak buruk dalam } \\
\text { menghadapi } \\
\text { mekanisme hukum } \\
\text { di pengadilan }\end{array}$ & $\begin{array}{l}\text { berdampak kepada } \\
\text { sulitnya untuk } \\
\text { mewujudkan } \\
\text { keadilan dalam } \\
\text { penyelesaian } \\
\text { hubungan industrial }\end{array}$ \\
\hline 2 & $\begin{array}{l}\text { Penelitian tentang } \\
\text { Hubungan } \\
\text { Industrial di } \\
\text { Jabodetabek, } \\
\text { Bandung dan } \\
\text { Surabaya Pada } \\
\text { Era Kebebasan } \\
\text { Berserikat }\end{array}$ & $\begin{array}{l}\text { Tim Peneliti } \\
\text { SMERU dibawah } \\
\text { kordinator Sri } \\
\text { Kusumastuti } \\
\text { Rahayu }\end{array}$ & $\begin{array}{l}\text { isu-isu yang } \\
\text { berkaitan di luar } \\
\text { upah menunjukkan } \\
\text { bahwa aspek-aspek } \\
\text { hubungan industrial } \\
\text { telah berfungsi lebih } \\
\text { mulus ketimbang } \\
\text { yang mungkin } \\
\text { diharapkan di tingkat } \\
\text { perusahaan }\end{array}$ & \begin{tabular}{|l|} 
kebijakan \\
dan peraturan \\
perundangan \\
pemerintah yang \\
mempengarui \\
kehidupan ekonomi \\
pekerja atau buruh, \\
khususnya yang \\
terkait dengan isu \\
upah memberikan \\
kontribusi terhadap \\
munculnya aksi-aksi \\
pemogokan dan \\
demonstrasi pekerja/ \\
buruh
\end{tabular} & $\begin{array}{l}\text { Kebanyakan } \\
\text { perselisihan dapat } \\
\text { di selesaikan pada } \\
\text { tingkat dialog } \\
\text { bipartit, belum } \\
\text { sampai kepada } \\
\text { dialog tripartit. } \\
\text { Menunjukkan bahwa } \\
\text { dalam konteks } \\
\text { hubungan bipartit, } \\
\text { kedua belah pihak } \\
\text { mulai menemukan } \\
\text { titik terang, namun } \\
\text { begitu mereka yang } \\
\text { berselisih mengaku } \\
\text { masih dalam proses } \\
\text { tahap belajar dalam } \\
\text { menemukan metode } \\
\text { negosiasi yang baik. }\end{array}$ \\
\hline 3 & $\begin{array}{l}\text { Penelitian tentang } \\
\text { Pelaksanaan } \\
\text { Penyelesaian } \\
\text { Perselisihan } \\
\text { Hubungan } \\
\text { Industrial Dalam } \\
\text { Melindungi } \\
\text { Kepentingan } \\
\text { Pekerja/Buruh }\end{array}$ & Ariani Arifin & $\begin{array}{l}\text { penyelesaian PHI } \\
\text { secara bipartit } \\
\text { dan mediasi telah } \\
\text { terlaksana secara } \\
\text { optimal sehingga } \\
\text { mampu melindungi } \\
\text { kepentingan pihak } \\
\text { pekerja/buruh }\end{array}$ & \begin{tabular}{|l|} 
pengadilan \\
hubungan industrial \\
belum terlaksana \\
secara optimal, \\
karena masih \\
banyak perselisihan \\
pemutusan \\
hubungan kerja yang \\
penyelesaiannya \\
lebih dari 50 hari \\
dan biaya yang \\
dikeluarkan lebih \\
besar dari standar \\
biaya yang telah \\
ditetapkan
\end{tabular} & $\begin{array}{l}\text { Faktor penghambat } \\
\text { penyelesaian } \\
\text { PHI: terputusnya } \\
\text { komunikasi, } \\
\text { keterbatasan } \\
\text { informasi, } \\
\text { kurangnya kesadaran } \\
\text { akan masalah yang } \\
\text { dihadapi, sumber } \\
\text { daya manusia } \\
\text { pada pengadilan } \\
\text { hubungan industrial, } \\
\text { pikiran tentang } \\
\text { menang atau kalah, } \\
\text { proses perundingan } \\
\text { yang panjang, } \\
\text { domisili pihak } \\
\text { pengusaha. } \\
\text { Faktor pendukung } \\
\text { penyelesaian } \\
\text { PHI: mediator } \\
\text { yang kredibel } \\
\text { (terpercaya), } \\
\text { memiliki } \\
\text { kepercayaan diri } \\
\text { (self confidence), } \\
\text { menguasai } \\
\text { substansi materi dan } \\
\text { menguasai teknik } \\
\text { komunikasi }\end{array}$ \\
\hline
\end{tabular}




\begin{tabular}{|c|c|c|c|c|c|}
\hline No. & Penelitian & Oleh & Temuan & Masalah & Hasil \\
\hline 4 & $\begin{array}{l}\text { Tesis dengan } \\
\text { judul Pengaruh } \\
\text { Lembaga Kerja } \\
\text { Sama Bipartit } \\
\text { Dan Peraturan } \\
\text { Perusahaan } \\
\text { Terhadap } \\
\text { Hubungan } \\
\text { Industrial Di Citic } \\
\text { Seram Energy } \\
\text { Limited }\end{array}$ & $\begin{array}{l}\text { Wahyu Tri } \\
\text { Winarko }\end{array}$ & $\begin{array}{l}\text { Lembaga Kerja } \\
\text { Sama Bipartit } \\
\text { memiliki pengaruh } \\
\text { yang signifikan } \\
\text { terhadap Hubungan } \\
\text { Industrial yakni } \\
\text { sebesar } 74 \% \text {. Hasil } \\
\text { regresi sederhana } \\
\text { juga menunjukkan } \\
\text { bahwa hubungan } \\
\text { salah satu indikator } \\
\text { Lembaga Kerja } \\
\text { Sama Bipartit } \\
\text { bahwa lembaga } \\
\text { tersebut dapat segera } \\
\text { menindaklanjuti } \\
\text { hasil konsultasi } \\
\text { dengan para } \\
\text { pekerja, terlihat } \\
\text { memiliki pengaruh } \\
\text { yang cukup besar. } \\
\text { Apabila hal ini } \\
\text { dikaitkan dengan } \\
\text { hasil distribusi } \\
\text { frekuensi dimana } \\
\text { terdapat persepsi } \\
\text { dari sebagian } \\
\text { besar responden } \\
\text { (sebanyak } 41 \text { orang } \\
\text { atau 53.9 \%) yang } \\
\text { menginginkan } \\
\text { respon yang segera } \\
\text { dari Lembaga Kerja } \\
\text { Sama Bipartit }\end{array}$ & $\begin{array}{l}\text { Forum komunikasi } \\
\text { bipartit belum } \\
\text { pro aktif dalam } \\
\text { mensikapi atau } \\
\text { memberikan solusi } \\
\text { dalam perselisihan } \\
\text { hubungan industrial } \\
\text { di perusahaan ini. Ini } \\
\text { di dapat dari hasil } \\
\text { jumlah responden } \\
\text { yang menyatakan } \\
\text { bahwa forum itu } \\
\text { belum terlalu } \\
\text { aktif lebih banyak } \\
\text { daripada yang } \\
\text { menyatakan sudah } \\
\text { aktif. }\end{array}$ & $\begin{array}{l}\text { Teori Social } \\
\text { Exchange Thibault } \\
\text { dan Kelley tentang } \\
\text { rewards, costs, } \\
\text { outcomes dan level } \\
\text { of comparisons. } \\
\text { Melalui keempat } \\
\text { hal ini, perilaku } \\
\text { organisasi antara } \\
\text { pengusaha dan } \\
\text { pekerja dapat } \\
\text { digambarkan. }\end{array}$ \\
\hline
\end{tabular}

Disamping fungsinya sebagai kota penghubung, Kota Kudus termasuk kota yang ramai, karena sebagaimana diketahui, Kudus adalah terhitung kota Industri. Dilihat dari jenis industrinya, terdapat tiga jenis industri andalan daerah ini, yaitu industri tembakau, industri percetakan, penerbitan dan kertas, dan industri makanan dan minuman.

Diantara berbagai jenis industri di daerah ini, industri tembakau/rokok merupakan salah satu industri yang berperan signifikan. Peran industri rokok yang cukup signifikan tercermin juga dalam realisasi ekspor daerah ini. Kontribusi ekspor rokok kretek mencapai 31,09 persen dari keseluruhan nilai ekspor daerah ini. (http://jatengprov.go.id/id/profil/ kabupaten-kudus. 1 Januari 2016)

Diakui atau tidak, sektor industri rokok telah mewarnai dinamika masyarakat Kota Kretek selama bertahun-tahun. Meskipun banyaksektor baruyang kinimulai berkembang dan dapat dibanggakan kemajuannya, belum ada yang dapat menggantikan posisi rokok dalam memberikan kontribusi. 


\section{Pertumbuhan Ekonomi Kabupaten Kudus}

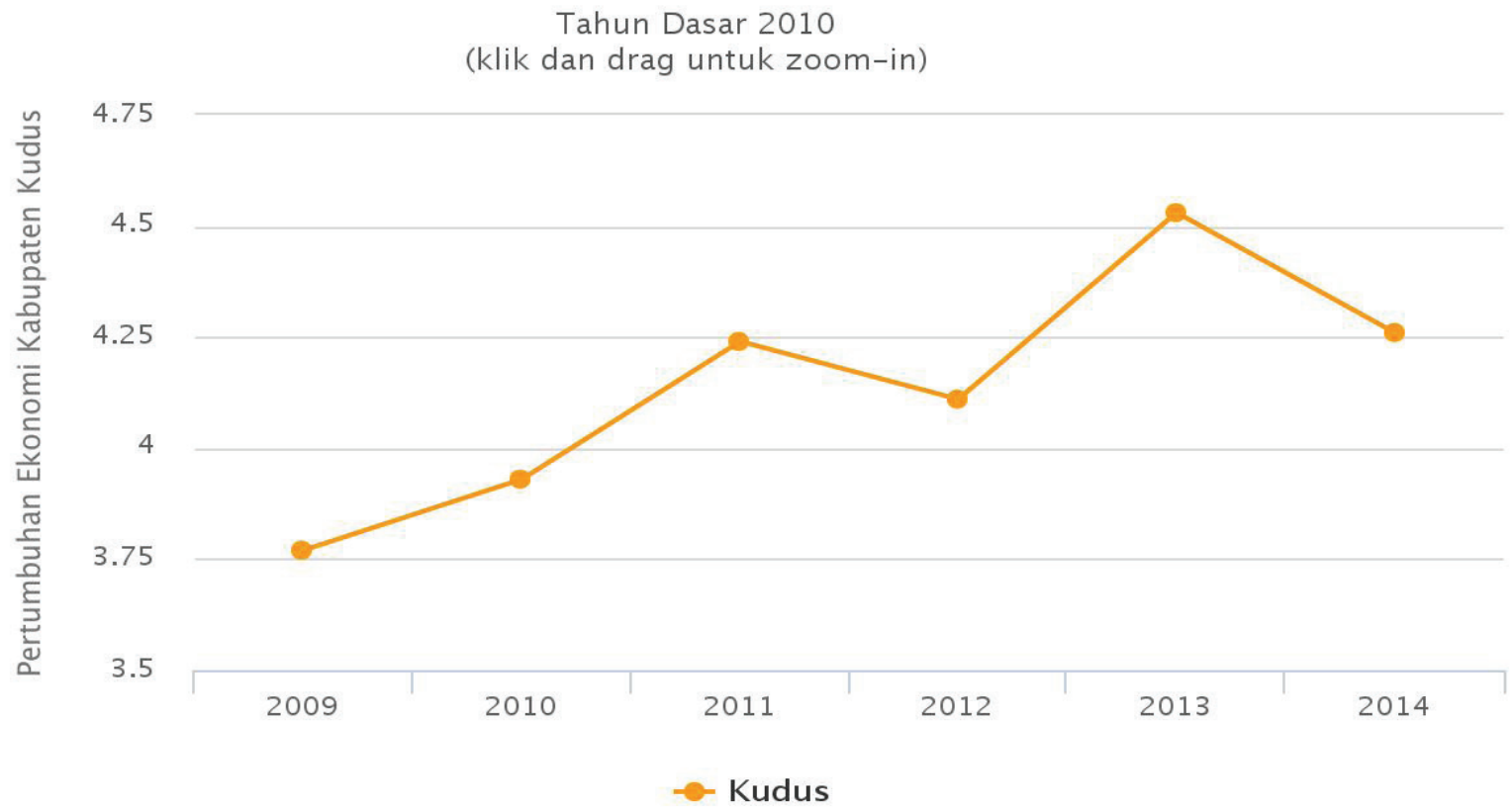

Sumber : Badan Pusat Statistik Kabupaten Kudus

Pada bulan Juni 2016 Kudus mengalami inflasi yang terjadi di Semarang, Jawa Tengah inflasi sebesar 0,25 persen, lebih tinggi dari dan Nasional yang masing-masing terjadi bulan sebelumnya yang mengalami inflasi inflasi sebesar 0,43 persen, 0,41 persen dan sebesar 0,16 persen. Inflasi yang terjadi di 0,66 persen. Berikut data perusahaan industri Kudus pada bulan Juni ini lebih rendah dari dan nilai produksi di Kabupaten Kudus :

Banyaknya Seluruh Perusahaan Industri dan

Nilai Produksi di Kabupaten Kudus Tahun 2013 - 2014

\begin{tabular}{|c|c|c|c|c|}
\hline \multirow[b]{2}{*}{$\begin{array}{c}\text { Kecamatan } \\
\text { District }\end{array}$} & \multicolumn{2}{|c|}{2013} & \multicolumn{2}{|c|}{2014} \\
\hline & $\begin{array}{c}\text { Perusahaan/ } \\
\text { Unit Usaha } \\
\text { Company / Business } \\
\text { Unit }\end{array}$ & $\begin{array}{l}\text { Nilai Produksi } \\
\text { ( Juta Rp ) } \\
\text { Production Value } \\
\text { (Million Rp) }\end{array}$ & $\begin{array}{c}\text { Perusahaan/ } \\
\text { Unit Usaha } \\
\text { Company / Business } \\
\text { Unit }\end{array}$ & $\begin{array}{l}\text { Nilai Produksi } \\
\text { ( Juta Rp ) } \\
\text { Production Value } \\
\text { (Million Rp) }\end{array}$ \\
\hline (1) & (2) & (3) & (4) & (5) \\
\hline $\begin{array}{l}1 . \\
\text { Kaliwungu }\end{array}$ & 1.830 & $6.620 .537,17$ & 1.848 & $6.686 .742,54$ \\
\hline 2. Kota & 2.159 & $31.617 .568,52$ & 2.180 & $31.933 .744,21$ \\
\hline 3. Jati & 1.575 & 78.934.740,14 & 1.591 & $79.724 .087,54$ \\
\hline 4. Undaan & 472 & $588.177,94$ & 477 & $594.059,72$ \\
\hline 5. Mejobo & 1.804 & $677.037,38$ & 1.822 & $683.807,75$ \\
\hline 6. Jekulo & 1.065 & $1.019 .608,57$ & 1.076 & $1.029 .804,66$ \\
\hline 7. Bae & 1.270 & $7.833 .021,43$ & 1.283 & $7.911 .351,64$ \\
\hline 8. Gebog & 1.237 & $3.334 .080,76$ & 1.249 & $3.367 .421,57$ \\
\hline 9. Dawe & 1.398 & $1.628 .979,07$ & 1.412 & $1.645 .268,86$ \\
\hline Jumlah & 12.810 & $132.253 .750,98$ & 12.938 & $133.576 .288,49$ \\
\hline
\end{tabular}

Sumber : Dinas Perindustrian, Koperasi dan Usaha Mikro Kecil dan Menengah Kabupaten Kudus 
Adapun jumlah tenaga kerja berdasarkan angka tenaga kerja dari tahun 2013 - 2014, hasil sensus yang dilakukan oleh BPS Kudus sebagai mana tabel berikut : jumlah tenaga kerja menunjukan penambahan

Banyaknya Seluruh Perusahaan Industri dan Jumlah Tenaga Kerja di Kabupaten Kudus Tahun 2013 - 2014

\begin{tabular}{|c|c|c|c|c|}
\hline \multirow[b]{2}{*}{$\begin{array}{c}\text { Kecamatan } \\
\text { District }\end{array}$} & \multicolumn{2}{|c|}{2013} & \multicolumn{2}{|c|}{2014} \\
\hline & $\begin{array}{l}\text { Perusahaan/ } \\
\text { Unit Usaha } \\
\text { Company / } \\
\text { Business Unit }\end{array}$ & $\begin{array}{c}\text { Tenaga Kerja } \\
\text { Labour }\end{array}$ & $\begin{array}{l}\text { Perusahaan/ } \\
\text { Unit Usaha } \\
\text { Company / } \\
\text { Business Unit }\end{array}$ & $\begin{array}{c}\text { Tenaga Kerja } \\
\text { Labour }\end{array}$ \\
\hline (1) & (2) & (3) & (4) & (5) \\
\hline 1. Kaliwungu & 1.830 & 13.314 & 1.848 & 13.447 \\
\hline 2. Kota & 2.159 & 137.213 & 2.180 & 138.585 \\
\hline 3. Jati & 1.575 & 27.768 & 1.591 & 28.046 \\
\hline 4. Undaan & 472 & 2.028 & 477 & 2.049 \\
\hline 5. Mejobo & 1.804 & 4.606 & 1.822 & 4.652 \\
\hline 6. Jekulo & 1.065 & 5.518 & 1.076 & 5.574 \\
\hline 7. Bae & 1.270 & 30.555 & 1.283 & 30.861 \\
\hline 8. Gebog & 1.237 & 20.224 & 1.249 & 20.426 \\
\hline 9. Dawe & 1.398 & 6.336 & 1.412 & 6.399 \\
\hline Jumlah/Total & 12.810 & 247.562 & 12.938 & 250.039 \\
\hline
\end{tabular}

Sumber : Dinas Perindustrian, Koperasi dan Usaha Mikro Kecil dan Menengah Kabupaten Kudus

Banyaknya Pencari Kerja yang Mendaftar di Disnaker menurut Pendidikan dan Jenis Kelamin di Kabupaten Kudus, 2015

\begin{tabular}{|c|c|c|c|c|c|c|c|c|c|c|c|}
\hline \multirow{2}{*}{ Bulan } & \multirow{2}{*}{ lonth } & \multicolumn{2}{|c|}{ Tamat SD } & \multicolumn{2}{|c|}{ Tamat SLTP } & \multicolumn{2}{|c|}{ Tamat SLTA } & \multicolumn{2}{|c|}{ Tamat AK } & \multicolumn{2}{|c|}{ Tamat PT } \\
\hline & & L & $\mathrm{P}$ & L & $P$ & $\mathrm{~L}$ & $P$ & L & $\mathrm{P}$ & L & $P$ \\
\hline \multicolumn{2}{|l|}{ Januari/January } & 0 & 7 & 6 & 15 & 121 & 90 & 5 & 7 & 21 & 28 \\
\hline \multicolumn{2}{|c|}{ Februari/February } & 1 & 7 & 4 & 27 & 80 & 72 & 3 & 12 & 21 & \\
\hline \multicolumn{2}{|l|}{ Maret/March } & 0 & 6 & 22 & 42 & 119 & 106 & 2 & 3 & 17 & 18 \\
\hline \multicolumn{2}{|l|}{ April/April } & 1 & 10 & 12 & 57 & 96 & 84 & 1 & 3 & 19 & 27 \\
\hline \multicolumn{2}{|l|}{ Mei/Mei } & 2 & 6 & 16 & 51 & 274 & 312 & 2 & 10 & 16 & 23 \\
\hline \multicolumn{2}{|l|}{ Juni/June } & 1 & 3 & 6 & 19 & 247 & 304 & 3 & 5 & 16 & 13 \\
\hline \multicolumn{2}{|l|}{ Juli/July } & 0 & 5 & 13 & 24 & 250 & 224 & 2 & 4 & 18 & 22 \\
\hline \multicolumn{2}{|l|}{ Agustus/August } & 1 & 9 & 15 & 56 & 392 & 435 & 2 & 12 & 34 & 39 \\
\hline \multicolumn{2}{|c|}{ September/September } & 0 & 10 & 7 & 34 & 173 & 174 & 4 & 3 & 14 & 32 \\
\hline \multicolumn{2}{|l|}{ Oktober/October } & 0 & 12 & 8 & 31 & 162 & 157 & 4 & 14 & 24 & 45 \\
\hline \multicolumn{2}{|c|}{ November/November } & 0 & 21 & 8 & 25 & 182 & 152 & 6 & 13 & 31 & 71 \\
\hline \multicolumn{2}{|c|}{ Desember/December } & 2 & 18 & 3 & 7 & 137 & 127 & 10 & 13 & 28 & 29 \\
\hline & 2015 & 8 & 114 & 120 & 388 & 2233 & 2237 & 44 & 99 & 259 & 355 \\
\hline & 2014 & 13 & 57 & 111 & 218 & 2097 & 2019 & 59 & 118 & 297 & 537 \\
\hline Jumlah & 2013 & 7 & 105 & 124 & 368 & 2744 & 2691 & 2236 & 402 & 707 & 1103 \\
\hline \multirow[t]{2}{*}{ Total } & 2012 & 14 & 101 & 122 & 364 & 3457 & 3536 & 125 & 291 & 530 & 713 \\
\hline & 2011 & 11 & 91 & 119 & 374 & 3940 & 4126 & 105 & 213 & 249 & 32 \\
\hline
\end{tabular}

Sumber : Dinas Sosial, Tenaga Kerja dan Transmigrasi Kabupaten Kudus. 
Kebutuhan Hidup Layak dan Upah Minimum Kabupaten Kudus, 2005-2015 (Rupiah)

$\begin{array}{ccc}\text { Tahun } & \text { KHL } & \text { UMK } \\ 2005 & 655.476,00 & 650.000,00 \\ 2006 & 684.679,06 & 672.500,00 \\ 2007 & 764.064,69 & 750.694,00 \\ 2008 & 786.910,00 & 775.000,00 \\ 2009 & 852.736,00 & 840.000,00 \\ 2010 & 889.568,52 & 889.000,00 \\ 2011 & 1.004 .157,00 & 990.000,00 \\ 2012 & 1.183 .447,99 & 1.150 .000,00 \\ 2013 & 1.183 .447,99 & 1.150 .000,00 \\ 2014 & 1.183 .447,99 & 1.380 .000,00 \\ 2015 & 1.183 .447,99 & 1.608 .200,00\end{array}$

Sumber : Dinas Sosial, Tenaga Kerja dan Transmigrasi Kabupaten Kudus.

Adapun serikat pekerja Kabupaten Kudus adalah sebagai berikut:

1. Serikat Pekerja RTMM (Rokok Tembakau Makanan dan Minuman)

Ketua : Andreas Hoa,

Jumlah Pekerja : 99.924

2. Serikat Pekerja TSK (Tekstil, Sandang konveksi/garmen)

Ketua : Jasri

Jumlah Pekerja : 2139

3. Serikat Pekerja TI (Transportasi)

Ketua : Daru Handoyo,SH.MH

Jumlah Pekerja : 2801

4. Serikat Pekerja NIBA (Niaga dan

Perbankan)

$\begin{array}{ll}\text { Ketua } & : \text { Drs.Ahmad Fikri } \\ \text { Jumlah Pekerja } & : 481\end{array}$

5. Serikat Pekerja FARKES (Farmasi dan Kesehatan)

Ketua : A.Fadlan.A.Md.Kep

Jumlah Pekerja : 305

6. Serikat Pekerja LEM (Listrik Electro)

Ketua : Khariri,SH.MH

Jumlah Pekerja : 2150

7. Serikat Pekerja PAR (Pariwisata)

Ketua : M.Yusrul

Jumlah Pekerja : 87

8. Serikat Pekerja PPP (Perkebunan,

Pertanian, Pertanian)

Ketua : Edi Subagyo

Jumlah Pekerja : 182

9. Serikat Pekerja KAHUT (Kehutanan)

Ketua : Kamludin

Jumlah Pekerja : 498
10. Serikat Pekerja SPBU (Pom Bensin)

$$
\begin{array}{ll}
\text { Ketua } & : \text { M.Faizin,S.Ag., S.Pd } \\
\text { Jumlah Pekerja } & : 64
\end{array}
$$

11. Serikat Pekerja PKSI (Pendidik dan Kependidikan)

Ketua : Bin Subiyanto M

Jumlah Pekerja : 187

Secara umum pengusaha menghendaki untuk mengendalikan biaya produksi termasuk biaya untuk pekerja (personnel cost) sesuai dengan kemampuan dan budget yang dialokasikan, sementara serikat pekerja/buruh menghendaki kenaikan upah dan perbaikan kesejahteraan pekerja dan keluarganya semaksimal mungkin. Di sisi lain, sejatinya kedua pihak juga mempunyai kepentingan yang sama yakni tumbuh kembangnya dan sukses yang optimal usaha perusahaan (Wiyono dan Hakim, 2009).

Organisasi yang dibutuhkan buruh adalah serikat buruh, tetapi kenyataannya banyak buruh tidak menyadari bahwa Serikat Pekerja adalah hak yang melekat bagi buruh (Worker Rights is Human Rights) seperti yang tercantum dalam Deklarasi Universal Hak Asazi Manusia Pasal 23: ayat (1) Setiap orang berhak atas pekerjaan, berhak bebas memilih pekerjaan, berhak atas syarat-syarat pekerjaan yang adil dan menguntungkan serta berhak atas perlindungan akan pengganguran; ayat (2) Setiap orang tanpa diskriminasi, berhak atas pengupahan yang sama untuk pekerjaan yang sama; ayat (3) Setiap orang yang bekerja berhak atas pengupahan yang adil dan 
menguntungkan, yang memberikan jaminan kehidupan yang bermartabat baik dirinya sendiri maupun keluarganya, dan jika perlu ditambah dengan perlindungan sosial lainnya; ayat (4) Setiap orang berhak mendirikan dan memasuki serikat-serikat pekerja untuk melindungi kepentingannya.

Beberapa buruh mengungkapkan bahwa suara perorangan kecil kemungkinan untuk didengarkan, maka dari itu mereka para buruh mengajukan diri menjadi anggota serikat buruh. Pun demikian adanya serikat pekerja mampu memperjuangkan adanya Perjanjian Kerja Bersama yang jelas seperti berapa upah yang akan diterima, bagaimana jam kerja, bagaimana perlindungan yang diberikan oleh perusahaan, memperjuangkan pengaturan golongan karyawan, dll.

Serikat pekerja yang berada pada perusahaan di Kudus berdasarkan hasil wawancara di atas diketahui telah diberi ruang untuk tumbuh dan berkembang oleh perusahaan. Hampir tidak ada kendala komunikasi antara pengurus dengan perusahaan. Perusahaan senantiasa membuka pintu dialog dan komunikasi untuk menyelesaikan beragam persoalan yang menyangkut pekerja atau karyawan. Situasi yang positif ini tak lepas dari faktor usia organisasi serikat pekerja itu sendiri.

Seperti terlihat pada hasil di atas, serikat pekerja terlibat dalam pengambilan keputusan yang krusial khususnya terhadap penentuan imbalan ekonomis maupun nonekonomis. Ini terlihat dari isu-isu yang ditangani, mulai dari penyusunan Perjanjian Kerja Bersama (PKB) hingga masalah sensitif seperti PHK karyawan.

Tujuan hubungan Industrial adalah pengemban cita-cita Proklamasi Kemerdekaan Negara Republik Indonesia 17 Agustus 1945 di dalam pembangunan nasional ikut mewujutkan masyarakat yang adil dan makmur berdasarkan Pancasila dan Undang-Undang Dasar 1945 serta ikut melaksanakan ketertiban dunia yang berdasarkan kemerdekaan, perdamaian abadi dan keadilan sosial.

Untuk mencapai tujuan tersebut harus diciptakan ketenangan, ketertiban, kegairahan kerja serta ketenangan usaha, meningkatkan kesejahteraan pekerja serta derajatnya sesuai dengan harkat dan martabat sebagai manusia. Kesepakatan kerja bersama sebagai realisasi dari konsep hubungan Industrial maka tujuannya mengacu pada tujuan konsep hubungan Industrial.

Serikat Pekerja sebagai wakil buruh di Kudus melihat pentingnya kegiatan ini, sehingga masalah hubungan industrial mendapat perhatian khusus dalam penanganannya, karena berpengaruh besar terhadap kelangsungan proses produksi yang terjadi di perusahaan.

\section{Pemahaman buruh Terhadap Peraturan dalam Forum Bipartit}

Dalam perjalanannya, forum bipartit belum sepenuhnya dipahami oleh para buruh. Yang mereka ketahui adalah apabila mereka mendapat masalah dalam perselisihan hubungan industrial, ada tempat yang mereka tuju untuk mengadukan perselisihan tersebut. Mereka tahu melalui lembaga itu, dapat mengutarakan usul dan harapan yang diinginkan. Padahal lebih dari itu forum bipartit mampu bernegosiasi mengenai apa yang seharusnya menjadi hak-hak serta kewajiban-kewajiban pengusaha dan buruh.

\section{Hambatan Komunikasi Buruh dan} Pengusaha Dalam Membangun kemitraan

Hambatan dalam komunikasi buruh dan pengusaha dalam membangun kemitraan dapat dikelompokkan dalam 3 kategori yaitu:

1. Hambatan Kondisional

Hambatan kondisional dari sisi buruh timbul karena keadaan buruh memiliki tingkat pendidikannya relatif rendah yaitu ada yang tidak tamat SD ditambah lagi dengan mayoritas buruh yang ada tidak memiliki ketrampilan yang memadai sehingga memiliki posisi tawar yang bagus kepada perusahaan. Hal ini menimbulkan anggapan dalam pihak pengusaha bahwa buruh adalah kelompok orang yang membutuhkan pekerjaan untuk mendapatkan upah dari pengusaha, karena kondisi ini buruh kondisinya masih memprihatinkan. 
2. Hambatan Kultural

Kultur yang ada saat ini adalah perilaku pemilik modal yang kurang menerima kehadiran Serikat Pekerja di perusahaan sebab dianggap momok bagi perusahaan karena akan melahirkan banyak tuntutan yang harus dipenuhi oleh perusahaan. Pengusaha akhirnya memanfaatkan kondisi buruh. Kondisi buruh yang bahwa mayoritas pendidikan pekerja rendah akhirnya memicu pengusaha untuk memenuhi syarat pembentukan serikat pekerja yang dibidani oleh manajemen.

3. Hambatan Fungsional

Keadaan organisasi ketenagakerjaan dalam menjalankan mekanisme organisasi, termasuk pengelolaan organisasi serta tata kerjanya masih dalam tahap mencari, menyesuaikan dan dibenahi.

\section{Simpulan}

Berdasarkan pengalaman buruh, kondisi buruh di Kudus tidak mengalami perubahan yang cukup berarti. Buruh masih dihadapkan pada persoalan pemenuhan hakhak normatif yang belum sesuai dengan harapan mereka. Selain itu, buruh juga dihadapkan pada persoalan kepastian status mereka. Pemberlakuan sistem kontrak di perusahaan-perusahaan banyak merugikan buruh, karena posisi mereka dalam sistem kontrak tersebut sangat lemah dan rentan terhadap pemutusan hubungan kerja (PHK). Namun buruh tidak banyak menuntut karena menurut mereka itu lebih baik daripada mereka tidak bekerja dan tidak mendapatkan penghasilan.

Serikat buruh yang diharapkan mampu memperjuangkan hak-hak buruh, informan menyatakan bahwa mereka belum mampu menjalankan perannya secara optimal karena tidak cukup memiliki kekuatan tawar menawar (bargaining power) yang memadai ketika berhadapan dengan pengusaha.

Sebagaimana diketahui bahwa relasi yang ada antara Serikat Pekerja dengan Pengusaha adalah relasi kuasa yang tidak setara. Serikat buruh terkesan sekadar ada, para pengurus serikat buruh sebatas menyampaikan usulan, namun keputusan tetap berada ditangan pengusaha. Para pengurus juga cenderung mencari posisi aman agar keberadaan mereka sebagai bagian dari perusahaan tetap terjaga. Mereka pada akhirnya lebih memilih bersikap pasif dan tidak terlalu membela kepentingan buruh. Itulah akhirnya banyak buruh menyebutkan bahwa Serikat Pekerja yang ada hanya boneka permainan pengusaha.

\section{Daftar Pustaka}

Hafsah, Mohammad Jafar. (1999). Kemitraan Usaha: Konsepsi dan Strategi. Jakarta: Pustaka Sinar Harapan.

Jehani, Libertus. (2007). Hak-Hak Pekerja Bila diPHK. Jakarta: Demedia Pustaka.

Kuswara Engkus. (2005). Tradisi Fenomenologi pada Penelitian Komunikasi Kualitatif: Sebuah pengalaman akademis. Jurnal Mediator Vol.7 No.1 Juni 2006 Terakreditasi Dirjen Dikti SK No.56/ DIKTI/Kep/2005.

Mudjiyanto, Bambang dan Kenda N. 2011. "Metode Fenomenologi Sebagai Salah Satu Metodologi Penelitian Kualitatif dalam Komunikologi”, Jurnal Penelitian Komunikasi dan Opini Publik. (diakses 25 Maret 2014)

Nurachmad, Muh. (2009). Tanya Jawab Seputar Hak-Hak Tenaga Kerja Kontrak (Outsourcing). Jakarta: Visimedia.

Tjandra, Surya. (2003). UU Ketenagakerjaan dalam Konteks Gejala Informalisasi Hubungan Kerja dalam UUK: Legalisasi "Perbudakan Modern"? Jurnal Analisis Sosial, Vol. 8. No. 3 Desember 2003

Winarko, Wahyu Tri. (2010). Pengaruh Lembaga Kerja Sama Bipartit Dan Peraturan Perusahaan Terhadap Hubungan Industrial Di Citic Seram Energy Limited. Tesis. Universitas Indonesia 
Wiyono dan Abdul Hakim. (2009). Pengaruh

Gaya Kepemimpinan, Motivasi dan

Kemitraan Serta Kepuasan Kerja

Terhadap Kinerja Pegawai, Jurnal

Riset Bisnis Indonesia Vol. 5 Januari

2009. Semarang: MM UNISSULA

http://strategihukum.net/kiat-sukses-

pengusaha-berunding-bipartit-alam-

perselisihan-hubungan-industrial. 25

Maret 2014

http://jatengprov.go.id/id/profil/kabupaten-

kudus. 1 Januari 2016 